\title{
Postoperative wound assessment in cattle: How reliable is the back hand palpation?
}

\author{
Ioannis Proios ${ }^{1 *}$, Marian Kusenda ${ }^{2}$, Christian Seiler $^{3}$, Carsten Siewert $^{3}$, Hermann Seifert $^{3}$ and Martin Kaske ${ }^{4}$
}

\begin{abstract}
Background: As part of clinical wound assessment in bovine surgery, discrepancies in skin temperature are evaluated by placing the back of the hand on the area to be examined. Generally, an increased skin temperature at the wound site for a prolonged period is considered as an indicator of impaired wound healing.

The aim of this study was to verify the reliability of palpation under bovine practice conditions using laparotomy as an example. Fourteen cows (German Holstein) with a left displacement of the abomasum (LDA) without other severe concurrent diseases were examined preoperatively and once daily for ten days after surgery. The skin temperature of the wound site in the right flank was assessed by palpation, followed by thermographic evaluation using an infrared camera after a 45-min acclimatisation period, under standardised conditions in a closed examination room daily for 10 days.

Results: All the incisions healed without clinical detectable perturbances. The ambient temperature range during the study period was $7.8-24.1^{\circ} \mathrm{C}$. Two groups were retrospectively defined according to the ambient temperature: high ambient temperature (HT group; median: $20.2{ }^{\circ} \mathrm{C} 25 / 75$ quartile: $18.5^{\circ} \mathrm{C} / 21.7{ }^{\circ} \mathrm{C} ; n=6$ ) and low ambient temperature (LT group; $10.8^{\circ} \mathrm{C} ; 9.4^{\circ} \mathrm{C} / 12.8^{\circ} \mathrm{C} ; n=8$ ). The temperature differences $(\Delta \vartheta)$ between the mean skin temperature of the wound site and a defined reference area cranial to the wound were assessed. A significant negative correlation was found between the ambient temperature $\left(\vartheta_{\mathrm{Amb}}\right)$ and $\Delta \vartheta(r=-0.51 ; P<0.001)$. The $\Delta \vartheta$ was postoperatively higher in the cows in the LT group (median of the individual animals $0.8-2.5^{\circ} \mathrm{C}$ ) than in the HT group $\left(0.1-0.5^{\circ} \mathrm{C} ; P<0.05\right)$. In contrast to the thermographic findings, manual palpation rarely detected local hyperthermia $\left(>1^{\circ} \mathrm{C}\right)$ at the wound site (sensitivity 0.20; specificity 0.96).

Conclusions: The infrared thermography provides a more reliable assessment of temperature changes at the wound site in comparison to manual palpation. The ambient temperature markedly affects the extent of local hyperthermia at the wound site.
\end{abstract}

Keywords: Cows, Infrared imaging, Laparotomy, Palpation, Skin temperature, Thermography, Wound healing

\section{Background}

Standing flank laparotomy is a commonly used procedure in cows. Disturbed postoperative wound healing can delay the recovery of cows and thus increase treatment costs. The wound healing process is usually assessed clinically by inspection and palpation. Important diagnostic evidence

\footnotetext{
* Correspondence: ioannis.proios@tiho-hannover.de

${ }^{1}$ Clinic for Cattle, University of Veterinary Medicine Hannover, Foundation, Hannover, Germany

Full list of author information is available at the end of the article
}

regarding wound healing could be provided by determining several clinical parameters, and the surface temperature of the wound site is one of them [1]. Although an inflammatory phase occurs during the physiological course of wound healing, a profoundly increased skin temperature at the wound edges for a longer period of time is considered as a sign of impaired wound healing [2, 3]. Thus, during palpatory examination of cows, deviations in skin temperature are at least qualitatively checked by using the back of the examiner's hand [4]. In human medicine, on the other

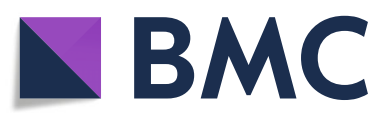

(c) The Author(s). 2021 Open Access This article is licensed under a Creative Commons Attribution 4.0 International License, which permits use, sharing, adaptation, distribution and reproduction in any medium or format, as long as you give appropriate credit to the original author(s) and the source, provide a link to the Creative Commons licence, and indicate if changes were made. The images or other third party material in this article are included in the article's Creative Commons licence, unless indicated otherwise in a credit line to the material. If material is not included in the article's Creative Commons licence and your intended use is not permitted by statutory regulation or exceeds the permitted use, you will need to obtain permission directly from the copyright holder. To view a copy of this licence, visit http://creativecommons.org/licenses/by/4.0/. The Creative Commons Public Domain Dedication waiver (http://creativecommons.org/publicdomain/zero/1.0/) applies to the data made available in this article, unless otherwise stated in a credit line to the data. 
hand, the palpation assessment of skin temperature appears to be subjective and quite unreliable [5]. Non-invasive infrared (IR) thermography is suitable for an objective and quantitative assessment of the skin temperature in the wound area [6-8], thus providing an indication of circulatory disorders, inflammation and impaired wound healing.

The aim of the present study was to investigate the reliability of palpation in estimating skin temperature under working conditions. Therefore, we compared the results of the palpation assessment of the skin temperature with the IR thermography measurements during the postoperative period of cows undergoing right flank laparotomy and omentopexy.

\section{Methods}

\section{Experimental animals}

Fourteen dairy cows (German Holstein) admitted to the Clinic for Cattle of the University of Veterinary Medicine Hannover Foundation, Hannover, Germany due to a left-sided displacement of the abomasum were included in this prospective study. Based on a comprehensive clinical investigation, cows did not suffer from a further accompanying disease.

\section{Timeline of interventions}

As part of the usual preoperative preparation [9], the right flank was first washed with lukewarm water and soap in a preparation room, shaved extensively and wiped dry with a towel. The cows were then taken to the adjacent and unheated examination room.

All cows were administered procaine penicillin $\mathrm{G}$ once daily for four days, beginning the day of surgery $(30,000$ $\mathrm{IU} / \mathrm{kg}$; s.c.; Procain-Penicillin G ad us. vet. "; aniMedica $\mathrm{GmbH}$, Senden-Bosensell, Germany). Meloxicam was also administered preoperatively $(0.5 \mathrm{mg} / \mathrm{kg}$; s.c.; Meta$\mathrm{cam}^{\circ}$; Boehringer Ingelheim Pharma GmbH \& Co. KG, Ingelheim, Germany).

After the preoperative measurements, the animal was taken to the operating theatre.

The shaved right flank was cleansed with $70 \%$ ethyl alcohol and povidone iodine solution (Vet-Sept ${ }^{\circ} 10 \%$, Albrecht $\mathrm{GmbH}$, Aulendorf, Germany). The distal paravertebral block was combined with a linear infiltration of the abdominal wall at the incision sites (laparotomy and omentopexy wound). For the locoregional flank anaesthesia $180 \mathrm{ml}$ procaine hydrochloride with epinephrine were used (Isocain $^{\odot} 2 \%$; Selectavet Dr. Otto Fischer, Weyarn-Holzolling, Germany). The flank was then cleansed once again with povidone iodine solution.

The abomasal displacement was corrected through a right flank approach and an omentopexy performed using a button-plate combination $[10,11]$. The abdominal wall was closed in three layers in accordance with the standard closure technique of our clinic. The skin and the external oblique abdominal muscle were closed together with five modified interrupted vertical Donati sutures (Silk ${ }^{\circ}$ USP 8; SMI AG, St. Vith, Belgium).

The surgical wound was treated with chlortetracycline spray (Chlortetracycline-Spray'; Novartis Tiergesundheit $\mathrm{GmbH}$, Munich, Germany). The duration of the operation and the length of the incision were documented for each case. In order to minimise the surgeons' interindividual impact on wound healing, the cows were operated exclusively by two experienced veterinary clinic assistants.

Following surgery, each animal received $200 \mathrm{ml}$ propylene glycol orally twice a day for five days. Clinical examination and the specific wound assessment of the incision by palpation and IR image were performed daily from day 1 to 10 post operationem (p. op) at 10:00 on each day in the same examination room, which was protected from sunlight and draughts. Daily examinations were performed always by the same person (I.P.). After being discharged from the clinic on the 10th day after surgery, information concerning the animal's performance and the aspect of the surgical wound was investigated through a telephone interview with the animal's owner between day 30 and 60 after surgery.

\section{Assessment of data}

The ambient temperature and humidity in the examination room were documented using a digital thermohygrometer $\left(\mathrm{GMH}^{\circ} 3330\right.$ Greisinger electronic $\mathrm{GmbH}$, Regenstauf, Germany).

Inspection of the wound was carried out to assess any swelling or exudation of the incision. Palpation focused on skin temperature by placing the back (dorsal surface) of the hand alternately in the area next to the incision (wound area) and about $20-30 \mathrm{~cm}$ cranial to the wound on the reference area (Fig. 1). Thus, it was palpatorically estimated whether the skin of the wound area was colder, normal or warmer in comparison to the reference area. Furthermore, the consistency of the wound area (soft, firm, rubbery, fluctuating or emphysematous) and its sensitivity to compression were determined through palpation (according to the defensive response of the cow). All these aspects of clinical examination of the wound area were evaluated with a grading system (Table 1).

To guarantee a standardised vertical IR image in relation to the sagittal surface of the animals, the cows were fixed in a stand with a front interception lock during the examination. The distance between the IR camera and the right flank was constantly $2.5 \mathrm{~m}$, and the distance of the IR camera from the ground $1.2 \mathrm{~m}$ (Fig. 2).

The daily postoperative IR image was taken after a 45min acclimatisation period using an IR camera (IR Flex$\mathrm{Cam}^{\circ} \mathrm{R} 2$, GORATEC Technology GmbH \& Co. KG, 


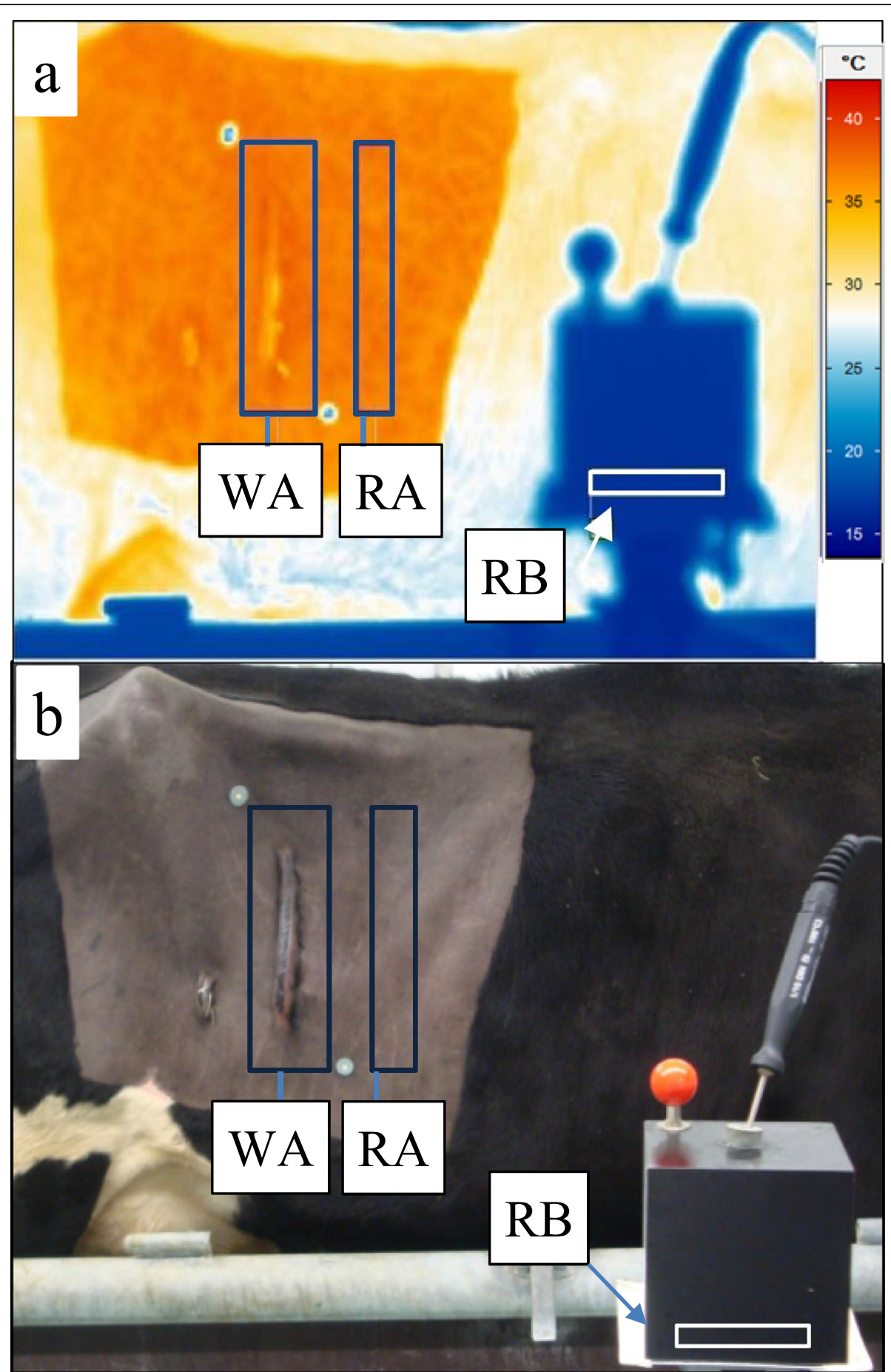

Fig. 1 IR image presented with the software IRBIS ${ }^{\oplus 3}$ plus (a) and digital picture (b) of the right flank of cow postoperatively. Schematic illustration of the defined skin areas: WA = wound area, $R A=$ reference area cranial of the laparotomy wound, $R B=$ measured area of the reference body

Erding, Germany) with the entire right flank of the cow being mapped. The IR camera operated in a spectral range of $8-12 \mu \mathrm{m}$. The image matrix of the microbolometer sensor consisted of $160 \times 120$ pixels (interpolated internally to $320 \times 240$ pixels). The thermal resolution was in accordance with manufacturer's specifications of
$70 \mathrm{mK}$. The accuracy of the absolute temperature measurement of the IR camera in accordance with the manufacturer's specifications was $\pm 2{ }^{\circ} \mathrm{C}$ or $\pm 2 \%$ [12]. The IR camera was switched on ten minutes prior to the shooting. The IR camera was auto-calibrated immediately before each image to eliminate homogeneity errors. The 
Table 1 Grading system for clinical wound assessment

\begin{tabular}{|c|c|c|c|c|}
\hline & \multicolumn{4}{|c|}{ clinical wound assesment score } \\
\hline & 0 & 1 & 2 & 3 \\
\hline Swelling & none & slight ( $<1 / 3$ the periwound surface) & $\begin{array}{l}\text { moderate }(1 / 3-2 / 3 \text { the } \\
\text { periwound surface })\end{array}$ & $\begin{array}{l}\text { severe }>2 / 3 \text { the periwound } \\
\text { surface }\end{array}$ \\
\hline Consistency & soft & firm-rubbery & emphysematous & fluctuating \\
\hline Exudation & none & slightly odourless discharge & $\begin{array}{l}\text { a great amount of odourless } \\
\text { discharge }\end{array}$ & malodorous discharge \\
\hline Sensitivity to compression & none & slight & moderate & severe \\
\hline Palpation (skin temperature) & normal & $\begin{array}{l}\text { colder or warmer in comparison to } \\
\text { the reference area }\end{array}$ & & \\
\hline
\end{tabular}

emissivity $\varepsilon$ of the skin was set at 0.98 , as previously reported in the literature $[13,14]$. The absolute temperature measurements were subsequently adjusted using a reference body, adapted to the room temperature displayed on every IR image (Fig. 1). The reference body used in this study was a cube of copper sheet filled with water with a matt black front side coating with an integrated stirrer (Leslie's Cube, Cornelsen Experimenta $\mathrm{GmbH}$, Berlin, Germany). The reference body was positioned on a tripod ( $1.15 \mathrm{~m}$ above the ground) and at a distance of one metre from the IR camera (Fig. 2). The reference body was left in the examination room throughout the study to be in constant thermal equilibrium with the ambient temperature. By moving the stirrer gently up and down, an almost equal temperature distribution of the water inside the cube and an even heat radiation from the black front side were achieved. The temperature of the reference body was measured and recorded during the investigation using a precision thermometer $\left(\mathrm{GMH}^{\circ} 370\right.$; GREISING ER electronic $\mathrm{GmbH}$ ). For correcting the absolute temperatures of each IR image, the difference in temperature of the reference body measured by the IR camera and the temperature measured with the thermometer was calculated for each image. The result was subtracted from the corresponding IR image.
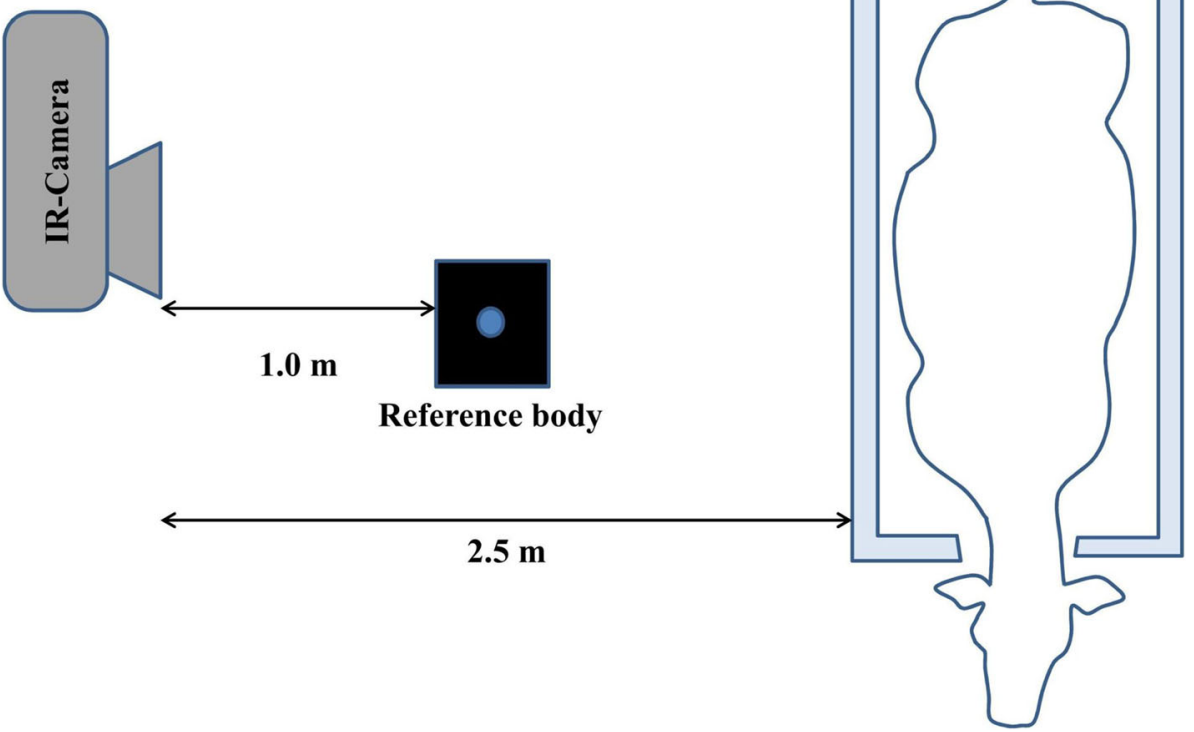

Fig. 2 Schematic illustration of the measuring set-up for infrared thermography. The reference body was continuously positioned at a specific point in front of the IR camera and in this way it appeared in each IR image of the right flank of the cow 
The IR images were evaluated using the Region of Interest (ROI) analysis method to minimise the timerelated drift error of the temperature measurement [15]. For this purpose, two easy-to-locate skin areas were determined: the wound area (WA) as the "target area" and the reference area (RA). The temperature differences $(\Delta 9)$ were calculated between the mean temperatures of the WA $\left(\vartheta_{\mathrm{WA}}\right)$ and the RA $\left(\vartheta_{\mathrm{RA}}\right)$. An accurate outline of the wound area in the right flank was achieved by two metallic rings $(\varnothing 2.5 \mathrm{~cm})$, which were temporarily attached caudodorsally and cranioventrally to the incision line at defined points with double-sided adhesive tape. The exact positions were determined using a rightangled triangle template (hypotenuse $9.3 \mathrm{~cm}$ ). These rings were clearly visible on the IR images and subsequently enabled a precise and reproducible determination of the ROIs (Fig. 1) and their evaluation. The thermography software IRBIS ${ }^{\oplus} 3$ Plus (Infratec $\mathrm{GmbH}$, Dresden, Germany) automatically calculated the mean temperatures of the defined skin areas of the WA ( $\left.\vartheta_{\mathrm{WA}}\right)$ and the RA $\left(\vartheta_{\text {RA }}\right)$ on every IR image.

\section{Evaluation of data}

The results for each parameter were tested for normal distribution using the Kolmogorov-Smirnov test. As the results were mostly not normally distributed, these were given as medians with 25 and $75 \%$ quartiles. The Wilcoxon (signed rank) test was used to compare the temperature measurements between different days (before and/or after the surgery), as well as the milk yield preoperatively and at day 10 after surgery. Correlations were calculated using the Spearman's rank correlation coefficient. The data were considered statistically significant when the probability of error was below $5 \%(P<$ $0.05)$. The sensitivity and specificity of the manual palpation detection of local hyperthermia of the skin were evaluated in relation to the objective IR thermographic measurements $\Delta \vartheta$. Sensitivity was defined as the ratio of the number of wounds with increased palpatory warmth to the number of wounds with increased temperature (based on IR thermographic measurements; temperature difference $>1{ }^{\circ} \mathrm{C}$ ).

The specificity was defined as the ratio of the number of wounds not found to be warm by palpation to the number of wounds that were not warm, based on IR thermographic measurements (temperature difference $<$ $1{ }^{\circ} \mathrm{C}$ ). Based on studies in equine medicine, where a temperature difference of up to $1{ }^{\circ} \mathrm{C}$ between two anatomically symmetrical skin areas is considered normal [16], the crucial temperature difference was set at $1{ }^{\circ} \mathrm{C}$ in our study.

The cows were retrospectively assigned to two groups according to the ambient temperature $\left(\vartheta_{\mathrm{Amb}}\right)$ using the
Cluster Procedure with $\mathrm{SAS}^{\odot}$ (Version 9.1, Statistical Analysis System Institute INC., Cary, NC, USA).

\section{Results}

On the day of surgery as well as during the postoperative period (day 1 to 10), all cows showed an undisturbed general condition and physiological rectal temperature $\left(38.6{ }^{\circ} \mathrm{C}\right.$; $38.4{ }^{\circ} \mathrm{C} / 39.0{ }^{\circ} \mathrm{C}$; median; Q1 / Q3). The milk yield increased from the day of surgery (16.0 l; $10.3 \mathrm{l} /$ 17.8 l; median; Q1 / Q3) until discharge on day 10 (22.0 l; $23.51 / 28.3$ l; $P<0.001$ ). Seven cows showed mild ketonuria and another five cows showed moderate ketonuria. Mild metritis was diagnosed in five cows. The median duration of the surgery (excluding anaesthesia) was $44 \mathrm{~min}$ (42 min / $48 \mathrm{~min}$; Q1 / Q3).

The length of the surgical wound $(20.3 \mathrm{~cm} ; 19.6 \mathrm{~cm} /$ $21.7 \mathrm{~cm}$; median; Q1 / Q3) as well as the thickness of the everted sutured skin edges $(1.8 \mathrm{~cm} ; 1.7 \mathrm{~cm} / 1.9 \mathrm{~cm})$ remained constant throughout the postoperative period.

Every wound healed per primam (primary intention healing) [17]. Slight soft swelling of the wound was observed in all cows at day 1 to 3 p. op. In most cases (62\%), the wound area was swollen ventrally. The wound area did not seem to be sensitive to palpation and was assessed as being warmer in comparison to the reference skin area in only 17 out of 140 palpation assessments (12\%).The wound area was never assessed palpatorically colder than the reference skin area.

In three cows, at days 1 and 2 p. op., slightly dried bloody outflow at the incision site was noticed. Beyond this, no exudation was observed. In four cows, a small skin patch was visible just on the first day after surgery, ventral to the transverse processes of the second lumbar vertebrae (LV). This temporary superficial skin change was not inside the RA outline.

The omentopexy incision was clinically normal in all cows but one where swelling was observed at days 9 and 10. The wound area above omentopexy site showed neither pressure pain nor remarkable temperature change through palpation. The ambient temperature $\left(\vartheta_{\mathrm{Amb}}\right)$ in the examinations room varied from 7.8 to $24.1{ }^{\circ} \mathrm{C}$ during the ten-month study period. Therefore, the cows were retrospectively classified into two groups based on the ambient temperature $\left(\vartheta_{\mathrm{Amb}}\right)$ using the Cluster Procedure with $\mathrm{SAS}^{\oplus}$ (Version 9.1, Statistical Analysis System Institute INC., Cary, NC, USA).

- Measurements at a relatively high ambient temperature $\left(\vartheta_{\mathrm{Amb}}\right)$ of $20.2^{\circ} \mathrm{C}\left(18.5^{\circ} \mathrm{C} / 21.7^{\circ} \mathrm{C}\right.$; HT group; $n=6)$.

- Measurements at a relatively low ambient temperature $\left(\vartheta_{\mathrm{Amb}}\right)$ of $10.8{ }^{\circ} \mathrm{C}\left(9.4{ }^{\circ} \mathrm{C} / 12.8{ }^{\circ} \mathrm{C}\right.$; $\mathrm{LT}$ group; $n=8$ ). 
The median relative humidity in the examination room in the HT group was $67.4 \%(60.0 \% / 76.0 \%)$ and in the LT group $75.5 \%$ (70.0\% / 83.0\%).

The mean skin temperature in the reference area $\left(\vartheta_{\mathrm{RA}}\right)$ strongly correlated with the ambient temperature $(r=$ $0.71 ; P<0.001$; Table 2 ), but only weakly with the rectal temperature $(r=0.28 ; P<0.001)$. The preoperative $\vartheta_{\text {RA }}$ was lower compared to postoperative measurements (day1- day10) in the HT group $\left(32.3{ }^{\circ} \mathrm{C} ; 31.8{ }^{\circ} \mathrm{C} /\right.$ $\left.32.6{ }^{\circ} \mathrm{C}\right)$ as well as in the LT group $\left(29.1{ }^{\circ} \mathrm{C} ; 28.6{ }^{\circ} \mathrm{C} /\right.$ $\left.30.0^{\circ} \mathrm{C} ; \mathrm{P}<0.01\right)$. The $9_{\mathrm{RA}}$ did not vary significantly in the postoperative period (between two different postoperative days). The median $\vartheta_{\mathrm{RA}}$ in the postoperative period was $35.6{ }^{\circ} \mathrm{C}\left(35.0{ }^{\circ} \mathrm{C} / 36.1{ }^{\circ} \mathrm{C}\right)$ for cows in the HT group and $32.1{ }^{\circ} \mathrm{C}\left(30.9{ }^{\circ} \mathrm{C} / 33.0{ }^{\circ} \mathrm{C}\right)$ for cows in the LT Group.

The mean skin temperature of the wound area $\left(9_{\mathrm{WA}}\right)$ correlated with the ambient temperature $(r=0.69 ; P<$ 0.001 ; Table 2). In the postoperative period, the $\vartheta_{\mathrm{WA}}$ was lower in both groups only at day 1 (d1) compared to other postoperative measurements $(\mathrm{d} 2-\mathrm{d} 10 ; P<0.01)$.

The $\Delta 9$ was postoperatively higher for cows in the LT group (median of the individual animals $0.8-2.5^{\circ} \mathrm{C}$ ) than in the HT group $\left(0.1-0.5{ }^{\circ} \mathrm{C} ; P<0.05\right)$. A negative correlation between $\Delta 9$ and $\vartheta_{\text {Amb }}$ was observed postoperatively $(r=-0.51 ; \quad P<0.001 ;$ Table 2$)$. The subjective impression of an elevated temperature $\left(>1{ }^{\circ} \mathrm{C}\right)$ in the wound area compared to the surrounding skin was given in 17 (12\%) of the total 140 manual palpations (Table 3). In these 17 wound assessments, which were palpatorically considered as warmer, $\Delta 9$ was $1.8{ }^{\circ} \mathrm{C}\left(1.1{ }^{\circ} \mathrm{C} /\right.$ $\left.2.1^{\circ} \mathrm{C}\right)$. The $\Delta 9$ of the wounds $(n=123)$, which were not characterised by palpation as increased warmth, was significantly lower at $0.7{ }^{\circ} \mathrm{C}\left(0.2^{\circ} \mathrm{C} / 2.0^{\circ} \mathrm{C} ; P<0.05\right)$.

For the subjective manual assessment of $\Delta 9$, a sensitivity of $20 \%$ and a specificity of $96 \%$ (for all cows in the study) were calculated. The assessment of skin temperature by palpation in cows in the HT group showed a significantly higher sensitivity $(43 \%)$ than in the LT group (18\%), and a very high specificity value was also calculated for the individual groups (Table 4). A total of 55 measurements $(4 / 51 ; \mathrm{HT} / \mathrm{LT})$ were false negative and three measurements $(2 / 1)$ were false positive (Table 3). The exact distribution is shown in Fig. 3.

\section{Discussion}

IR thermography is a non-contact imaging method for measuring the thermal radiation of surfaces. This allows indirect estimation of blood flow changes and tissue metabolic activity [18]. Injuries or inflammation usually alter blood flow to affected tissues [19]. "Calor" (heat) as a cardinal symptom of inflammation is the result of increased blood flow [16]. Thus, a significant warming of a skin area may be an expression of inflammatory changes in the underlying tissues [20, 21]. In clinical practice, variations in skin temperature are checked by palpation during the clinical examination by using the dorsal surface of the examiner's hand $[4,22]$. The importance of hand hygiene palpating a surgical wound with ungloved hands should not be underestimated in order to minimise the risk of a nosocomial wound infection.

In this study, all the incisional wounds of the treated cows were covered with a chlortetracycline spray instead of an (adhesive) gauze dressing pad so as to avoid any skin irritation, which could have an impact on the thermographic measurements. In addition, the use of a micronised aluminum spray was not preferred, as it may cause reflections and could affect the IR measurements. All cows were administered procaine penicillin for four days, as this was the former standard procedure in our clinic at the time of the study. Taking into account the importance of prudent use of antibiotics, we would no longer suggest the perioperative use of antibiotics in non-complicated LDA surgery. The use of an antibiotic spray as wound protectant on incisions should also be avoided.

In this study, always the same person performed this examination at varying ambient temperatures and his hands were not warmed up. The subjectivity of sensory impressions in human medicine may impair the early detection of wound infections. Therefore, the regular clinical evaluation of wounds makes more sense if the examinations are consistently carried out by the same physician [23].

The practical use of IR thermography has been investigated in several fields of veterinary medicine and different animal species $[24,25]$. In the present study, the sensitivity of the manual skin palpation of the wound area was very low compared to the objective

Table 2 Spearman's correlation coefficients between ambient temperature $\left(\vartheta_{\text {Amb }}\right)$, rectal temperature and infrared (IR) thermographic measurements in 14 cows determined on the day of surgery and during the postoperative phase

\begin{tabular}{llrl}
\hline Comparative parameters & & $\mathbf{r}$ & $\mathbf{P}$ \\
\hline Ambient temperature $\left(\vartheta_{\text {Amb }}\right)$ & Mean skin temperature of the reference area using IR thermography $\left(\vartheta_{\text {RA }}\right)$ & 0.71 & $<0.001$ \\
Ambient temperature $\left(\vartheta_{\text {Amb }}\right)$ & Mean skin temperature of the wound area using IR thermography $\left(\vartheta_{\text {WA }}\right)$ & 0.69 & $<0.001$ \\
Ambient temperature $\left(\vartheta_{\text {Amb }}\right)$ & IR thermographic temperature difference $\Delta \vartheta\left(\vartheta_{\text {WA }}-\vartheta_{\text {RA }}\right)$ & -0.51 & $<0.001$ \\
Rectal temperature & Mean skin temperature of the reference area using IR thermography $\left(\vartheta_{\text {RA }}\right)$ & 0.28 \\
\hline
\end{tabular}


Table 3 Evaluation of the wound temperature by palpation in comparison to the skin temperature measurements with the infrared camera (IRT)

\begin{tabular}{|c|c|c|c|c|c|c|}
\hline \multirow{3}{*}{$\begin{array}{l}\text { Number of } \\
\text { measurements }\end{array}$} & \multicolumn{3}{|c|}{ HT group } & \multicolumn{3}{|c|}{ LT group } \\
\hline & \multicolumn{3}{|c|}{ palpatorically } & \multicolumn{3}{|c|}{ palpatorically } \\
\hline & positive & negative & total & positive & negative & total \\
\hline IRT $>1{ }^{\circ} \mathrm{C}$ & 3 & 4 & 7 & 11 & 51 & 62 \\
\hline IRT $<1{ }^{\circ} \mathrm{C}$ & 2 & 51 & 53 & 1 & 17 & 18 \\
\hline total & 5 & 55 & 60 & 12 & 68 & 80 \\
\hline
\end{tabular}

LT: Group of cows whose measurements were taken at low ambient temperatures ( $n=8 ; 80$ measurements)

HT: Group of cows whose measurements were taken at high ambient temperatures ( $n=6 ; 60$ measurements)

thermographic measurements (20\%; Table 4). This result corresponds to findings in human medicine. Palpation is considered to be subjective and inaccurate. The temperature differences of approximately $2{ }^{\circ} \mathrm{C}$ are rarely detected with the hand in humans $[5,26]$. IR thermography is considered ten times more sensitive for assessing temperature differences than manual palpation [16].For patients with a high risk of developing diabetic foot disease, a daily bilateral temperature control using an IR-thermometer is recommended. Temperature differences of more than $2.2{ }^{\circ} \mathrm{C}$ are considered critical and require further diagnostic evaluation [26]. In a study in human patients, four low cost IR thermometers were validated (under constant ambient conditions) assessing the skin surface temperature of the wound. All the thermometers were highly reliable (intraclass correlation coefficient greater than $95 \%$ ). Accordingly, a handheld and more cost-effective IR thermometer (pyrometer) seems to be an appropriate alternative to an IR camera for assessing the wound temperature reliably with contactless measurements [27].

According to a new study, the palpation detection of a warmer skin surface is possible but not always effective (only $62 \%$ accuracy at $\Delta 9=1{ }^{\circ} \mathrm{C}$ ) despite strictly controlled environmental conditions. The efficiency rate depends on the temperature difference $(\Delta \vartheta)$ as well as on the experience of the clinician [28].

Ambient temperature is one of the most relevant environmental factors influencing skin temperature [29, 30]. In human medicine, the impact of ambient

Table 4 Sensitivity (SEN) and specificity (SPC) of the assessment of wound temperature by palpation

\begin{tabular}{llll}
\hline & HT group & LT group & Total \\
\hline SEN & 0.43 & 0.18 & 0.20 \\
SPC & 0.96 & 0.94 & 0.96
\end{tabular}

LT: Group of cows whose measurements were taken at high ambient temperatures ( $n=8 ; 80$ measurements);

HT: Group of cows whose measurements were taken at high ambient temperatures ( $n=6 ; 60$ measurements) temperature on skin temperature is of minor relevance, as the temperature in the examination room is less affected by seasonal changes. Thermographic measurements on large animals, on the other hand, are often difficult in practice due to the considerable temperature variation in the barn during the year. Similarly, Wilhelm et al. [31] noted that different ambient temperatures significantly impair the thermographic assessment of temperature differences between affected and healthy claws. Furthermore, Spire et al. [32] compared the surface temperature of beef cattle ears with or without steroids ear implants using an IR camera and noted that, thermoregulation in inflamed skin is different from normal skin. They also observed greater temperature differences in cases of cold and humid weather. Similar results were also reported in horses [33]. In the cited study, it was determined that the flank temperature was higher in pregnant than in non-pregnant mares. Ambient temperature influence on skin temperature was also observed. When ambient temperature was lower than $19{ }^{\circ} \mathrm{C}$, a higher temperature difference was evident.

In the present study, higher differences in temperature between the wound area and regular skin were recorded with the IR camera at lower ambient temperatures in comparison to higher ambient temperatures. There were six measurements in the low temperature group where the calculated $\Delta 9$ was higher than $4{ }^{\circ} \mathrm{C}\left(4.1-5.1{ }^{\circ} \mathrm{C}\right.$; Fig. 3). In fact, these individual $\Delta 9$ occurred due to the lowest temperature values of the $\vartheta_{\mathrm{RA}}$, which were determined on these days $\left(27.2-30.6{ }^{\circ} \mathrm{C}\right)$ and not because of an extremely high absolute temperature measurement of the wound area $\left(31.9-34.7^{\circ} \mathrm{C}\right)$. These temperatures were noticed in different cows and always on a different day after surgery (d4-d10). Nevertheless, in our study, the sensitivity of the palpation assessment of skin temperature was significantly lower on colder than on warmer days (Table 4). This is probably due to the fact that the thermoreceptors of the (not warmed up) hands are less sensitive at lower ambient temperatures (approx. $11^{\circ} \mathrm{C}$ ) and may not perceive temperature differences of approx. $1{ }^{\circ} \mathrm{C}$ at a skin temperature of approx. $33^{\circ} \mathrm{C}$.

In the present study, the healing of the incisional wounds $(n=14)$ was closely monitored thermographically. The slight swelling, which occurred in all cows exclusively between days 1 and 3 p. op. and mostly only in the ventral third of the wound, is thus consistent with clinical unimpaired wound healing. The undisturbed general condition of all cows (no fever, good feed intake) and their increasing milk yield during the ten-day postoperative period confirm a clinical recovery after the surgery. The telephone interviews conducted with the owners 30 and 60 days after surgery did not highlight the presence of clinically detectable disturbances of wound healing. A higher number of cows would be 


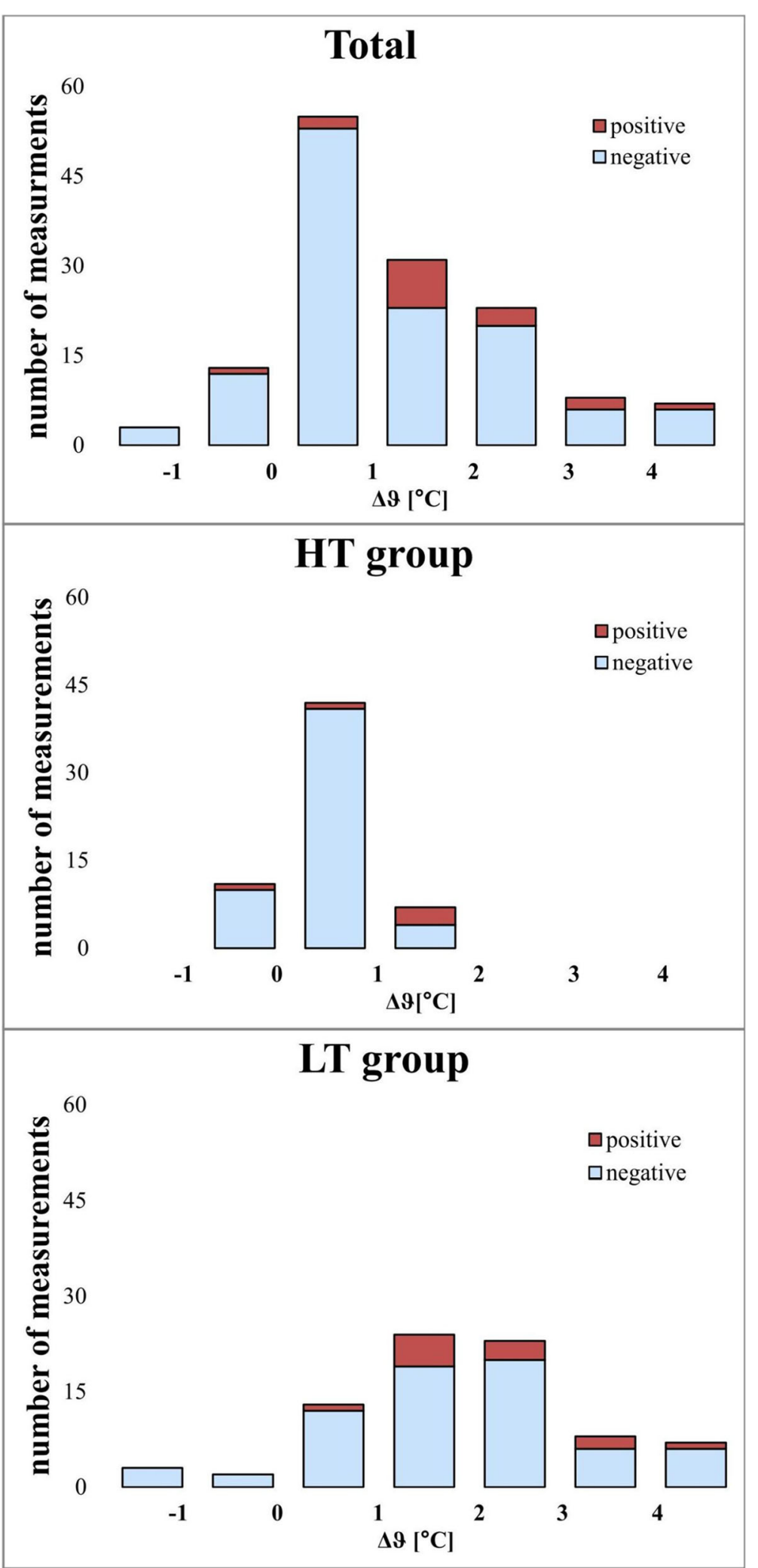

Fig. 3 (See legend on next page.) 
(See figure on previous page.)

Fig. 3 Distribution of thermographic temperature differences $(\Delta \vartheta)$ for all cows and for both groups in detail. The shaded blue area of the columns indicates the cows diagnosed palpatorically showing no increased warmth; the shaded red area indicates those cows diagnosed showing increased warmth. Total: includes all the cows $(n=14 ; 140$ measurements); LT: Group of cows whose measurements were taken at low ambient temperatures ( $n=8 ; 80$ measurements);HT: Group of cows whose measurements were taken at high ambient temperatures $(n=6$; 60 measurements)

desirable in principle to improve the statistical power of the results. On the other hand, the simultaneous inclusion of more cows in the study was only possible in exceptional cases due to the time-consuming diagnosis of the patients and the limited availability of pens and examination rooms. The fact that the $\vartheta_{\mathrm{RA}}$ was lower in both groups preoperatively than on the days after surgery may indicate that the recently washed and shaved flank was not completely acclimatised to the ambient temperature.

In our clinic, the distal paraverterbral block combined with a linear infiltration of the incision line represents the established standard flank anaesthesia method. The additional use of the infiltration block prevents an incomplete anaesthetic result occurring on the incisional area when using only the distal paravertebral block, as the nerve pathways can vary [34]. Using epinephrine can prove advantageous, as bleeding from the incision during the surgery is minimal. On the other hand, epinephrine may also favor local tissue necrosis. The temporary superficial skin change under the transverse processes of the second LV shown in four cows was similar to that in the skin area where the syringe was injected with local anaesthetic. This may be associated with the vasoconstrictive effect of epinephrine. No significant differences however were found between the postoperative days.

There were no sudden or intense changes in ambient temperature during the study period. The mean temperature variation from one day to the other was only $0.6{ }^{\circ} \mathrm{C}$. Rapid changes in ambient temperature (between days) would probably have made it more difficult to compare repeated measurements of skin temperature. Unanswered remains the question how the ambient temperature may affect the thermographic detection of a wound infection (the infection-induced warming of the skin). The present findings indicate that false negative diagnoses may occur in summer since the inflamed skin vessels are probably no longer proportionally dilatable as is the case in healthy skin. As a result, the entire flank appears warm. Furthermore, the short-term temperature increase in the wound area during the physiological healing process should not be considered as an incipient infection. This might lead to false positive diagnoses in winter. Therefore, additional studies should be carried out on cows with impaired wound healing.

\section{Conclusions}

The palpation estimation of the skin temperature in bovine practice does not seem to be sufficient for a reliable temperature assessment of the wound area. As a limiting parameter, the ambient temperature influences the value of manual palpation. At low ambient temperatures in particular, the palpation sensitivity is further reduced. In contrast, the examination using the objective IR thermography is much more precise. However, it requires a higher technical and temporal effort. Future investigations using the smaller and more cost efficient pyrometer would be warranted.

\section{Acknowledgements}

The authors wish to thank the animal keepers at the Clinic for Cattle, University of Veterinary Medicine, Hannover, Foundation for their careful preoperative preparation as well as for feeding and milking the cows during the study period.

\section{Authors' contributions \\ IP is the main author of this manuscript. He performed the measurements and data analyses. MKu operated the majority of the cows. ChS was involved in drafting and critically revising the manuscript regarding important intellectual content. MK, MKu, CaS and HS contributed to the conception and design. They were involved in drafting and revising the manuscript. All authors read and approved the final manuscript.}

\section{Prior publication}

Data have not been published previously in another scientific journal but some data were part of the dissertation "Charakterisierung des Verlaufs der Wundheilung mittels klinischer, labordiagnostischer, sonographischer, thermographischer und thermometrischer Befunde bei Milchkühen nach Laparotomie (Omentopexie nach Dirksen)" written by loannis Proios at the University of Veterinary Medicine Hannover, Foundation. Furthermore, data included in this article have previously been published in the Abstract book of the 46th Jahrestagung der Deutschen Gesellschaft für Medizinische Physik - German Society of Medical Physics. (Proios I, Siewert C, Kusenda M, et al).

\section{Funding}

This study was funded by the Clinic for Cattle and the Institute for General Radiology and Medical Physics of the University of Veterinary Medicine Hannover, Foundation. This publication was supported by the German Research Foundation (Deutsche Forschungsgemeinschaft) and University of Veterinary Medicine Hannover, Foundation within the funding programme Open Access Publishing. Open Access funding enabled and organized by Projekt DEAL.

\section{Availability of data and materials}

The datasets used and/or analysed during the current study are available from the corresponding author on reasonable request.

\section{Declarations}

Ethics approval and consent to participate

This study did not require official or institutional ethical approval. The animals were handled in accordance with high ethical standards and national legislation. All owners signed a consent for allowing us to publish the results of this study. 


\section{Consent for publication}

All owners signed a consent for allowing us to use the animals and all the medical data for scientific analysis.

\section{Competing interests}

The authors declare that they have no competing interests.

\section{Author details}

${ }^{1}$ Clinic for Cattle, University of Veterinary Medicine Hannover, Foundation, Hannover, Germany. ${ }^{2}$ Nord-Ostsee Tierärzte, Veterinary Practice, Schafflund, Germany. ${ }^{3}$ Institute for General Radiology and Medical Physics, University of Veterinary Medicine Hannover, Foundation, Hannover, Germany.

${ }^{4}$ Department for Farm Animals, Vetsuisse Faculty, Zurich, Switzerland.

Received: 25 November 2020 Accepted: 1 June 2021

Published online: 16 June 2021

\section{References}

1. Houghton VJ, Bower VM, Chant DC. Is an increase in skin temperature predictive of neuropathic foot ulceration in people with diabetes? A systematic review and meta-analysis. J Foot Ankle Res. 2013;6:31.

2. Robicsek F, Masters TN, Daugherty HK, Cook JW, Selle JG, Hess PJ, et al. The value of thermography in the early diagnosis of postoperative sternal wound infections. Thorac Cardiovasc Surg. 1984;32:260-5.

3. Horzic M, Maric K, Bunoza D. The temperature dynamics during the healing processing of a surgical wound. Biomed Tech (Berl). 1995;40:106-9.

4. Stöber M. Grundregeln der Untersuchungstechnik. Rosenberger G. Die klinische Untersuchung des Rindes 3rd ed. Berlin: Paul Parey; 1990 pp. 103-7.

5. Murff RT, Armstrong DG, Lanctot D, Lavery LA, Athanasiou KA. How effective is manual palpation in detecting subtle temperature differences? Clin Podiatr Med Surg. 1998;15(1):151-4.

6. Siah CJR, Childs C. Thermographic mapping of the abdomen in healthy subjects and patients after enterostoma. J Wound Care. 2015;24:112-20.

7. Nishide K, Nagase T, Oba M, Oe M, Ohashi Y, lizaka S, et al. Ultrasonographic and thermographic screening for latent inflammation in diabetic foot callus. Diabetes Res Clin Pract. 2009:85:304-9.

8. Romanò CL, Romanò D, Dell'Oro F, Logoluso N, Drago L. Healing of surgical site after total hip and knee replacements show similar telethermographic patterns. J Orthop Traumatol. 2011;12:81-6.

9. Heimberg P. Kontrollierte klinische Studie über die Behandlung von Kühen mit linksseitiger Labmagenverlagerung mittels perkutaner Abomasopexie (modifizierte Methode nach Sterner und Grymer) im Vergleich zur Omentopexie nach Laparotomie von rechts (Methode Hannover). Dr. Med Vet Thesis: University of Veterinary Medicine Hannover; 1999.

10. Dirksen G. Present state of diagnosis, treatment and prophylaxis of left displacement of bovine abomasum. Dtsch tierärztl Wschr. 1967;74:625-33.

11. Bückner R. Surgical correction of left displaced abomasum in cattle. Vet Rec. 1995;136:265-7.

12. Infrared Solutions. User Manual IR Flex ${ }^{\oplus}$ Cam R2 ; 2006

13. Montanholi YR, Lim M, Macdonald A, Smith BA, Goldhawk C, SchwartzkopfGenswein K, et al. Technological, environmental and biological factors: referent variance values for infrared imaging of the bovine. J Animal Sci Biotechnol. 2015;6:1-16.

14. Venjakob P, Borchardt S, Thiele G, Heuwieser W. Evaluation of ear skin temperature as a cow-side test to predict postpartum calcium status in dairy cows. J Dairy Sci. 2016;99:6542-9.

15. Siewert C, Danicke S, Kersten S, Brosig B, Rohweder D, Beyerbach M, et al. Difference method for analysing infrared images in pigs with elevated body temperatures. Z Med Phys. 2014;24:6-15.

16. Turner T. Diagnostic thermography. Vet Clin North Am Equine Pract. 2001; 17:95-113.

17. Kujath P, Michelsen A. Wounds - from physiology to wound dressing. Dtsch Arztebl Int. 2008;105:239-48.

18. Love TJ. Thermography as an indicator of blood perfusion. Ann N Y Acad Sci. 1980;335:429-37.

19. Turner T, Purohit RC, Fessler JF. Thermography: a review in equine medicine. Compend Contin Educ Vet. 1986:8:855.

20. Bhargava A, Chanmugam A, Herman C. Heat transfer model for deep tissue injury: a step towards an early thermographic diagnostic capability. Diagn Pathol. 2014;9:1-18.
21. Eddy AL, Van Hoogmoed LM, Snyder JR. The role of thermography in the management of equine lameness. Vet J. 2001;162:172-81.

22. Monahan FD. First Encounter: A general survey of the patient. In: Mosby's Expert Physical Exam Handbook: Rapid inpatient and outpatient assessment. Albany: Mosby Elsevier; 2009. p. 58.

23. Hansis U, Arens S. Störungen der Wundheilung. In: KNAPP U, HANSIS M, editors. Die Wunde. Stuttgart: Thieme Verlag; 1999. pp. 200-20.

24. Schaefer AL, Cook NJ, Bench C, Chabot JB, Colyn J, Liu T, et al. The noninvasive and automated detection of bovine respiratory disease onset in receiver calves using infrared thermography. Res Vet Sci. 2012;93:928-35.

25. Soerensen DD, Pedersen LJ. Infrared skin temperature measurements for monitoring health in pigs: a review. Acta Vet Scand. 2015;57:5.

26. Sibbald RG, Mufti A, Armstrong DG. Infrared skin thermometry: an underutilized cost-effective tool for routine wound care practice and patient high-risk diabetic foot self-monitoring. Adv Skin Wound Care. 2015;28(1):37-44.

27. Mufti A, Coutts P, Sibbald RG. Validation of commercially available infrared thermometers for measuring skin surface temperature associated with deep and surrounding wound infection. Advances in skin Wound care. 2015;28(1):11-6.

28. Levine $D$, Walker JR, Marcellin-Little DJ. Detection of skin temperature differences using palpation by manual physical therapists and lay individuals. J Man Manip Ther. 2018;26:97-101.

29. Dini V, Salvo P, Janowska A, Di Francesco F, Barbini A, Romanelli M. Correlation between wound temperature obtained with an infrared camera and clinical wound bed score in venous leg ulcers. Wounds. 2015;27:274-8.

30. Savary $P$, Hauser R, Ossent P, Jungbluth T, Gygax L, Wechsler B. Eignung der Thermographie zur Erfassung von Entzündungen an den Gliedmaßen von Mastschweinen. Dtsch tierärztl Wschr. 2008;115:324-9.

31. Wilhelm K, Wilhelm J, Fürll M. Use of thermography to monitor sole haemorrhages and temperature distribution over the claws of dairy cattle. Vet Rec. 2015;176:146.

32. Spire MF, Drouillard JS, Galland JC, Sargeant JM. Use of infrared thermography to detect inflammation caused by contaminated growth promotant ear implants in cattle. J Am Vet Med Assoc. 1999;215:1320-4

33. Bowers S, Gandy S, Anderson B, Ryan P, Willard S. Assessment of pregnancy in the late-gestation mare using digital infrared thermography. Theriogenology. 2009;72:372-7.

34. Skarda R. Local and regional anesthesia in ruminants and swine. Vet Clin North Am Food Anim Pract. 1996;12:579-626.

\section{Publisher's Note}

Springer Nature remains neutral with regard to jurisdictional claims in published maps and institutional affiliations.
Ready to submit your research? Choose BMC and benefit from:

- fast, convenient online submission

- thorough peer review by experienced researchers in your field

- rapid publication on acceptance

- support for research data, including large and complex data types

- gold Open Access which fosters wider collaboration and increased citations

- maximum visibility for your research: over $100 \mathrm{M}$ website views per year

At BMC, research is always in progress.

Learn more biomedcentral.com/submissions 